University of California, Hastings College of the Law UC Hastings Scholarship Repository

Faculty Scholarship

1962

\title{
The Early Evolution of the Common Law Writs: A Sketch
}

Geoffrey C. Hazard Jr.

UC Hastings College of the Law, hazardg@uchastings.edu

Follow this and additional works at: http://repository.uchastings.edu/faculty_scholarship

\section{Recommended Citation}

Geoffrey C. Hazard Jr., The Early Evolution of the Common Law Writs: A Sketch, 6 Am. J. Legal Hist. 114 (1962).

Available at: http://repository.uchastings.edu/faculty_scholarship/951

This Article is brought to you for free and open access by UC Hastings Scholarship Repository. It has been accepted for inclusion in Faculty Scholarship by an authorized administrator of UC Hastings Scholarship Repository. For more information, please contact marcusc@uchastings.edu. 


\section{Faculty Publications \\ UC Hastings College of the Law Library}

Author: Geoffrey C. Hazard, Jr.

Source: American Journal of Legal History

Citation: 6 Am. J. Legal Hist. 114 (1962).

Title: $\quad$ The Early Evolution of the Common Law Writs: A Sketch

Originally published in AMERICAN JOURNAL OF LEGAL HISTORY. This article is reprinted with permission from AMERICAN JOURNAL OF LEGAL HISTORY and James E. Beasley School of Law of Temple University. 


\title{
The Early Evolution of the Common Law
}

\author{
Writs: A Sketch*
}

by Geoffrey C. Hazard, JR. $\dagger$

WTILLIAM's CONQUEST OF ENGLAND in 1066 and the years following witnessed the superimposition of Norman feudal institutions on Anglo-Saxon royal and communal institutions and the subsequent emergence of a royal administrative and judicial system that was stronger than either of its predecessors and, indeed, perhaps the strongest in Europe. Very broadly, the Anglo-Saxon political structure was a decentralized association of communities, having origin in familial and tribal groups, dominated in varying degrees by local magnates of varying power, and presided over by a King with vague and generally feeble authority. For present purposes, the significant Anglo-Saxon institutions at the time of the conquest were the crown and the local tribunals. The crown, threoretically at least, had a responsibility to see that justice was done throughout the realm, i.e., had a direct legitimate interest in all disputes between man and man. The English crown also carried with its fiscal perquisites (most importantly, crown lands productive of income and the power to lay and collect national taxes) and the nucleus of an administrative organization. In point of fact, the rule of the English kings was mild and at times feeble. The stronger dynasty of William I, however, found in the power of justice and the power of the purse the means by which to rule with a firmer hand.

The other important English institution was the local tribunal. There were two principal kinds, the hundred courts (village-centered courts) and the shire courts (analogous to the county court). Communal forums, these courts by the

* This and the following article were papers read at the annual meeting of the West Coast Branch of the American Society for Legal History held at the School af Law, University of California, Berkeley, on September 30,1961. The third paper read on this program, by Prof. Thomas G. Barnes, will appear in the next issue.

$\dagger$ Professor of Law, University of California, Berkeley. 
time of the conquest had assumed a territorial jurisdiction in the sense that they were recognized as the appropriate tribunals of disposition of controversies arising in the territory in which they were located. The precise nature of their operations is still a matter of conjecture and debate, but several points seem clear. Both performed without differentiation functions that we would today call "administrative," such as ferreting out thieves, and "judicial"-determining who were the guilty. Both acted under at least nominal supervision of the crown, thus representing in theory at least the implementation of the royal interest in justice. The principal shortcoming of the local tribunals was that they were slow and uncertain in operation. Another shortcoming was that the common modes of trial were trial by ordeal and trial by compurgation. An important attraction was that in some cases they relied on the recognition as a means of ascertaining facts. A recognition was the act by which a group from the vicinage came together and stated on oath, that is "recognized," the facts of the matter in issue, e.g., that $A$ had owned certain cattle and that $B$, the accused, had taken them away. The recognition was one of the important roots of the common-law jury system. Furthermore, the court itself consisted of "suitors to court," presided over (in the shire court) by the sheriff. The suitors were the men of substance of the vicinage and attendance at court was an obligation of their status as such. The presence of suitors preserved the element of lay judging, also a tradition supporting jury trial. Whether the suitors and the recognitors were the same people, and, if not, what the relation between them may have been, is as yet undiscovered.

On top of this indigenous English institutional structure the invaders of 1066 erected the para-military feudal system. In theory and practice, it differed radically from the AngloSaxon institutions. The feudal hierarchy was a pyramid of power built on land grants descending in the first instance from William to his tenants-in-chief, from the tenants-in-chief to their feudal subordinates, and from these subordinates to the petty lords of the manor. Each member of the hierarchy held tenure in land and in status by grant from his immediate superior. The grant carried with it the burden of rendering services, principally that of providing mounted armed warriors 
-knights-to the grantee's superior, and the benefit of the superior's protection. It also carried with it the obligation of "suit of court," i.e., the duty to attend and participate in judgment in the feudal court held by the lord. Theoretically, and for the most part practically, each member of the hierarchy had complete authority and responsibility in respect to those holding from him, subject, however, to his responsibility to his own immediate superior. The lord's authority and responsibility included the power and duty to hold his feudal court and to render justice for his tenants. A peculiarity of the feudal courts, which came in time to be regarded as a serious shortcoming, was that they determined some issues by trial by battle as well as by the ordeal.

The jurisdictional lines between the Norman feudal courts and the English communal courts were various and uncertain. Suffice it to say that the feudal courts at one level or another of the hierarchy theoretically had jurisdiction over every kind of dispute that might arise between man and man, save for those between tenants of different lords. At the same time, the communal courts, nominally acting in the name of the king, had a very similar jurisdiction. In theory and practice, therefore, both king, acting through local courts, and lords, acting through feudal courts, had jurisdiction of any particular case. This unstable duality could not and did not last. Powerful lords swallowed up the hundred courts. And royal justice in time superseded the feudal courts and intruded upon the local courts. The history of the common law is the account of the royal supercession of the feudal and local courts.

As suggested above, the exercise of royal authority in a dispute between man and man could be justified under the Anglo-Saxon theory of the crown. William and his successors held that crown. But such an exercise would also constitute an intrusion into the feudal courts-an invasion of established jurisdiction, a derogation of constituted authority, a supercession of constituted officials and a capture of accustomed revenues (for running a court can be profitable, as speed-trap towns today are aware). Political adventures of this sort have always required caution and circumspection. Hence, assertion of royal jurisdiction was impeded both by theoretical limitations imposed by feudalism and practical objections raised by 
the barons. ${ }^{1}$ These considerations help explain the halting process by which the jurisdiction of royal authority was expanded.

The earliest forms of royal intervention were not strictly speaking judicial but executive or administrative. The occasion for these early interventions was a wrong, typically involving a breach of the peace, committed somewhere in the realm and unredressed by the local or feudal courts. For example, a landlord might assert that his tenant had not paid his feudal dues of produce and services. On that pretext, the lord would direct his retainers to oust the tenant and take over the land. The tenant, if convinced that he could get no remedy in his lord's court, would take his troubles to the king. If the case sounded serious enough, the king might direct the landlord to rectify the situation. ${ }^{2}$

The instrument of intervention was the writ. The writ was nothing more than a written directive from the king, witnessed and bearing his seal, directed to a royal official or to an individual or group of individuals ordering the addressees to do or refrain from doing a designated act. In the first half of the Twelfth Century, the Anglo-Norman kings not infrequently made such peremptory intrusions to enforce the peace of the realm which they by their coronation oath had sworn to uphold. An example of such a writ, from the reign of Stephen $(1135-54)^{3}$ is as follows:

"Stephen, king of the English, to the bishop of Norwich, greeting. I order you to reseise the monks of St. Edmunds of their church of Caistor as fully and justly as they were seised on the day when their abbot left for Rome. And if anything has since been taken away there,

1 The process of royal intrusion should not, however, be thought of as the execution of a pre-conceived putsch. Like most constitutional developments it was a series of ad hoc reactions which only in retrospect could be seen as following a pattern.

2 Cf. The modern-day intervention of executive officers, such as Presidents, governors and mayors, in disputes ordinarily cognizable before regular public or private forums, e.g., the collective bargaining table.

3 Reprinted and translated in VAN CaEnegem, Royal Writs in England from the Conquest to Glanvill 458-54 (Seld. Soc., 1959). 
let it be justly restored. And let them keep it in peace that no injury is done of them thereof.

"Witness: Aubrey de Ver. at Westminster."

This method of executive intervention afforded a swift and effective remedy but it also was easily abused. The writ issued upon the complaint of the alleged injured party: if he had misrepresented the facts, royal intervention would work not justice but injustice. The crown's desire to provide swift redress for wrong was tempered by its desire to be assured that wrong in fact had been done, an age-old dilemma in the administration of justice. In the Twelfth Century, this dilemma was solved in two different ways, both of which, however, resulted in bringing the case before royal officials. One method directed the sheriff, or some other official, to advise himself of the facts before proceeding to act. At first, the writs were silent on how the sheriff was to advise himself, but before long reliance was placed on recognition by men of the vicinage, i.e., a jury. An example of a writ of Henry II, issued sometime between 1155 and 1166 , is this one: ${ }^{4}$

"Henry, King of the English and duke of the Normans and of the Aquitanians and count of the Angevins, to the sheriff of Lincolnshire, greeting. I order that you have recognized without delay by the oath of lawful citizens of Lincoln whether the canons of Lincoln were seised of the land near the water of the city, which Martellus gave them, on the year and day when Henry, my grandfather, was alive and dead and if they were disseised afterwards unjustly and without judgment, then I order that they be reseised thereof without delay and justly and let them hold it well and in peace and justly and freely and quietly and honourably. And let them not be impleaded thereon until I come back to England, except on my command. And unless you do it, my justice shall.

"Witness: Manasser Biset, steward, at Tinchbrai."

By the other method, the alleged wrongdoer was ordered to right the wrong or to appear before the king or his justices and show cause why he had not done so. At the show cause

4 From Van CaEnegem, op. cit. supra note 3 , at 462. 
hearing the merits of the case would be determined. This form of writ was known as a "praecipe," from the Latin word for "order" appearing first after the greeting in the writ. An example, ${ }^{5}$ is the following:

"The king to the sheriff, greeting. Order N. to give back justly and without delay to $R$. a hundred marks which he owes him, so he says, and of which he complains that he deforces him unjustly. And if he does not do it, summon him by good summoners that he be before me or my justices at Westminster a fortnight after the octave of Easter to show why he has not done it. And have there with you the summoners and this writ.

"Witness: N. At M."

By this evolution, a writ which was originally an extraordinary executive interference with the normal course of feudal or local procedure became an ordinary judicial function of the crown.

There was, however, another parallel development which must be mentioned. This was the Norman, as distinct from Anglo-Saxon, device of the inquest. The inquest was brought to England with the conquest. It was an inquiry conducted by commissioned royal officials asking the people of a neighborhood what they knew about designated matters. The Domesday Book, the vast inventory of England taken at the direction of William I in 1086, was compiled from information gathered at a general royal inquest made for the purpose. In the years after Domesday, inquests were made from time to time upon special direction issuing from the king to his justices. Henry II, upon succeeding to the throne in 1154 after the disorderly rule of Stephen, determined to bring peace and order to the realm and in particular to rectify the wave of violent ousters that had occurred during the Anarchy. To this end in about 1166 he commissioned his justices to travel about the realm and hold inquests to determine what ousters"disseisins"- had occurred in recent years. This was the origin of the assize of novel disseisin, the term "assize" referring variously and ambiguously to the order directing the inquiry, to the inquiry itself, and to the findings upon the inquiry. At

5 From Van CaEnegem, op. cit. supra note 3, at 437. 
these inquests, men from the vicinage were called before the justices and required to state what recent disseisins had taken place, a procedure which, like the Anglo-Saxon recognition, place reliance on local talesmen for ascertainment of the facts.

The responses given at inquest, for example that $A$ had within recent years unjustly disseised $B$ of a certain manor in the shire, served as the basis for corrective orders in the form of writs from the king to the wrongdoer. The inquest was thus a quasi-criminal investigation aimed at restoring order, but resulting also in a private remedy for the injured party. Beyond its practical effectiveness, the assize of novel disseisin had the advantage that the right in the land in quest was established by testimony, rather than the traditional trial by battle, ordeal, or compurgation. Its popularity led Henry to send out subsequent commissioners of inquest and in rapid order it became available on request by any aggrieved person. i.e., it had become an ordinary private remedy available in king's court rather than an extraordinary remedy for restoration of the public peace. It reached this stage of development by the end of the reign of Henry II, about 1185 . The procedure was invoked of course by writ, such as this one: ${ }^{a}$

"The king to the sheriff, greeting. N. has complained to me that $\mathbf{R}$. has disseised him unjustly and without judgment of his free tenement in such a vill after my last crossing to Normandy. And therefore I command you that, if the said $\mathrm{N}$. gives you security for prosecuting his suit, you shall cause that tenement to be reseised of the chattels that were taken in it and the tenement with the chattels to be in peace till the Sunday after Easter. And in the meantime cause twelve free and lawful men of the vicinity to see that land and have their names put down in writing. And summon them by good summoners that they be then before me or my justices prepared to make recognition thereof. And put the said $R$. under gage and safe pledges - or his bailiffs in case he himself is not found-that he be there then to hear that recognition. And have there the summoners and this writ.

"Witness: M. At W."

6 From Van CAENEgem, op. cit. supra note 3 , at 464. 
Reflection on the foregoing discussion suggests the following generalizations:

1. The royal writs represented interferences with established feudal or local jurisdiction. In a real sense, in their genesis they were extraordinary remedies. This fostered a tradition that they were to be strictly construed in their application, i.e., that if a particular case was not within the terms of the writ the action founded on the writ would fail. This in part at least explains the tradition of technicality found in common law procedure, a tradition that has not completely died even to this day.

2. The royal writs were ad hoc responses to particular types of situations. Even when the number and variety of writs had so increased that one was available for most all types of cases, the tradition remained that a royal court acted not in exercise of a general power to do justice in cases brought before it, but in exercise of a special power conferred by the issuance and return of the writ. This phenomenon not only fostered the technicality referred to but also perpetuated a compartmentalization of the substantive law: Substantive law emerged in the form of pronouncements about the rights of the parties brought before a court in a writ proceeding. ${ }^{7}$ This peculiarity was, of course, the basis for Maitland's classic dictum that "forms of action we have buried, but they still rule us from their graves." 8

3. The writs were in the first instance executive directives. The method by which the propriety of their issuance was determined was in substance that by which any executive establishes his premises for action: such inquiry as the responsible officer deems sufficient to satisfy himself that action is necessary and appropriate. The evolution of writ procedure is the story of its judicialization, in which executive self-

7 This compartmentalization is, of course, still felt today. See, e.g., the provisions of statutes of limitations differentiating between the time bar on "an action for relief on the ground of fraud or mistake," e.g., Calif. Code Civ. Pro. \$338, subdiv. 4, and the time bar on "an action upon a . . . liability not founded upon an instrument in writing," e.g., Calif. Code Pro. $\$ 339$, subdiv. 1, even though a "liability" not founded upon an "instrument" (such as the liability to repay money wrongfully received) may arise as the result of "fraud."

8 MaItland, Equity and the Forms of Action, 296 (1909). 
satisfaction was displaced as the foundation for official action by the procedures of notice and hearing that are characteristic of adjudicatory process. Certainly one consequence of that displacement was the effacing of the chief original attractions of writ procedure, namely its speed and its decisiveness. The inference is that these attractions became dispensable as the crown strengthened its hand during the Twelfth Century, so that the relatively higher certainty of obtaining an enforceable decision was compensation for additional delay and difficulty in obtaining it. The further inference is that writ procedure slowed its pace for the same reasons that procedures for deciding questions of right and wrong seem always to have slowed: process that is "due" in such cases is process that is slow as compared with other methods of decisionmaking. As Judge Learned Hand not long ago observed, "Speed and hurry ought to be antipodes of judicial behavior." 9

- California Apparel Creators v. Wieder of California, Inc., 162 F. 2d 893, 903 (2d Cir. 1947) (dissenting opinion). 